\begin{tabular}{|l|l|l|}
\hline \multicolumn{2}{|c|}{ PublisherInfo } \\
\hline \hline PublisherName & $:$ & BioMed Central \\
\hline \hline PublisherLocation & $:$ & London \\
\hline \hline PublisherImprintName & $:$ & BioMed Central \\
\hline \hline
\end{tabular}

\title{
Natural calcineurin inhibitor
}

\begin{tabular}{|l|l|l||}
\hline \multicolumn{2}{|c|}{ ArticleInfo } \\
\hline \hline ArticleID & $:$ & 4667 \\
\hline \hline ArticleDOI & $:$ & $10.1186 /$ gb-spotlight-20030103-01 \\
\hline \hline ArticleCitationID & $:$ & spotlight-20030103-01 \\
\hline \hline ArticleSequenceNumber & $:$ & 19 \\
\hline \hline ArticleCategory & $:$ & Research news \\
\hline ArticleFirstPage & $:$ & 1 \\
\hline \hline ArticleLastPage & $:$ & 2 \\
\hline \hline & & RegistrationDate : 2003-1-3 \\
\hline ArticleHistory & $:$ & OnlineDate \\
\hline \hline ArticleCopyright & $:$ & BioMed Central Ltd2003-3 \\
\hline \hline ArticleGrants & $:$ & \\
\hline \hline ArticleContext & $:$ & 130594411 \\
\hline \hline
\end{tabular}




\section{Jonathan B Weitzman}

Email: jonathanweitzman@hotmail.com

FK506 is an immunosuppressive drug that inhibits the phosphatase activity of calcineurin, thereby interfering with normal signal transduction pathways. In an Advanced Online Publication in Nature Cell Biology Shirane and Nakayama from Kyushu University in Japan, describe a role for the mitochondrial FK506-binding protein 38 (FKBP38) in preventing apoptosis (Nature Cell Biology, 23 December 2002, DOI:10.1038/ncb894). They fished out FKBP38 in a yeast two-hybrid screen for Bcl-2-interacting proteins. FKBP38 co-immunoprecipitates with $\mathrm{Bcl}-2$ and the related $\mathrm{Bcl}-\mathrm{X}_{\mathrm{L}}$ protein. It also interacts with calcineurin, in a FK506-independent manner, and inhibits its phosphatase activity. FKBP38 regulates the cellular localization of $\mathrm{Bcl}-2$ and $\mathrm{Bcl}-\mathrm{X}_{\mathrm{L}}$, targeting them to the mitochondria and preventing apoptosis.

\section{References}

1. Calcineurin is a common target of cyclophilin-cyclosporin A and FKBP-FK506 complexes.

2. Nature Cell Biology, [http://www.nature.com/naturecellbiology]

3. Kyushu University, [http://www.kyushu-u.ac.jp/english/index-e.htm]

4. Isolation of a cDNA encoding a novel human FK506-binding protein homolog containing leucine zipper and tetratricopeptide repeat motifs. 